10IKC-363

\title{
PGE GEOCHEMISTRY OF DIAMONDIFEROUS AND NON-DIAMONIDFEROUS KIMBERLITES FROM EASTERN DHARWAR CRATON, SOUTHERN INDIA: IMPLICATION FOR UNDERSTANDING THE NATURE OF MANTLE BELOW DHARWAR.
}

\author{
Parijat Roy* and Balaram Vysetti \\ (Geochemistry Division, National Geophysical Research Institute \\ (Council of Scientific and Industrial Research, India), Hyderabad-500606 \\ Email:*parijatroy@yahoo.co.in)
}

\begin{abstract}
Among all known erupted mantle-derived magmas, kimberlites offer the deepest probes into the convecting subcontinental mantle, derived from the lowest degrees of melting and thus believed to provide direct sampling of lithospheric mantle beneath the cratons (Mitchell, 1986; Ringwood et al., 1992; Haggerty, 1994). Their isotope ratios, chemical compositions and their special occurrences in total, implies kimberlites can provide significant information on the chemical state of the Earth's deep interior (Kaminsky et al., 2004). The platinum-group elements (PGE) and gold are highly siderophile and chalcophile elements that can be used to document processes of mantle evolution as well as in the differentiation of a magma series, which the lithophile elements do not (Barnes et al., 1985, Mc Donald et.al. 1995). Hence PGE geochemistry can provide an additional insight into kimberlite geochemistry. The PGE investigation of these rocks plays an important role to discuss nature of mantle, mantle metasomatism, source and evolution of magma. The PGE data on Southern Indian diamondiferous kimberlites intruded in and around Anantapur area suggests that they are characterized by PGE concentrations $\Sigma$ PGE (Ir + $\mathrm{Ru}+\mathrm{Rh}+\mathrm{Pt}+\mathrm{Pd}$ ) range from 6.32 to $43.4 \mathrm{ppb}$ with a average of $27.5 \mathrm{ppb}$, and are higher than
\end{abstract}

the means of alkali basalts ( $\leq 1 \mathrm{ppb})$, Mid-ocean ridge basalts (MORB; $\leq 0.74 \mathrm{ppb}$ ) and oceanisland basalts (OIB; $\approx 3.25 \mathrm{ppb}$ ). The $\mathrm{Au}$ concentrations in Southern Indian kimberlites are extremely high when compared with the South African kimberlites. Ni concentrations and $\mathrm{Pd} / \mathrm{Ir}$ and $\mathrm{Ni} / \mathrm{Cu}$ ratios are higher to those of cratonic kimberlites of South Africa and Brazil. Two distinctly different patterns can be seen in the primitive mantle normalized plots for these kimberlites. Pipe 13, CC-2, CC4 and TK-4 shows positive $\mathrm{Rh}$ and negative $\mathrm{Pd}$ pattern while rest all the pipes shows negative $\mathrm{Rh}$ and flat to positive $\mathrm{Pt}$ and positive $\mathrm{Pd}$ pattern. There is a strong positive correlation between $\mathrm{Ni}$ and total PGE. Three distinct arrays can be observed. Noble metals reveal similar trend with $\mathrm{Zr} / \mathrm{Hf}$ ratios. With the increase of $\mathrm{Zr} / \mathrm{Hf}$ ratio, $\mathrm{Ir}, \mathrm{Ru}, \mathrm{Rh}, \mathrm{Pt}$ and $\mathrm{Pd}$ tends to increase. The higher $\mathrm{Pt} / \mathrm{Ir}$ ratios for on craton kimberlite samples from Dharwar Craton, indicates that the underlying mantle has been subjected to extensive metasomatism. It may also suggest that an unique PGE enrichment process during the source development might have taken place for these kimberlites irrespective of the nature of the underlying mantle. Whole rock PGE data thus appears to provide a means to assess the nature of the underlying mantle (depleted cratonic, 


\section{0 $^{\text {th }}$ International Kimberlite Conference, Bangalore - 2012}

fertile off cratonic) through which kimberlitic diatremes erupted. Further studies are going on to compare the PGE data with that of the nondiamondiferous kimberlite pipes from Southern India to understand the nature of mantle and source region variability between these pipes and to understand the nature of mantle below Dharwar craton during proterozoic period.

\section{References:}

Barnes S. J., Naldrett A. J. and Gotten M. P., 1985. The origin of the fractionation of platinum-group elements in terrestrial magmas. Chem. Geol. 53, 303-323.

Haggerty S.E., 1994. Superkimberlites: a geodynamic diamond window to the Earth's core. Earth and Planetary Science Letter, 122, 57-69.
Kaminsky FV, Sablukov SM, Sablukova LI, Channer DMD (2004) Neoproterozoic 'anomalous' kimberlites of Guaniamo, Venezuela:mica kimberlites of 'isotopic transitional' type. Lithos 76:565-590.

McDonald, I., De M.J., Smith, B., Bizzi, L.A.and Viljoen, K.S., 1995. The geochemistry of the platinum-group elements in Brazilian and southern African kimberlites, Geochimica Cosmochimica Acta, 59, 2883-2903.

Mitchell R. H., 1986. Kimberlites: mineralogy, geochemistry and petrology. Plenum, (New York), 442.

Ringwood, A. E., Kesson, S. E., Hibberson, W., and Ware, N., 1992. Origin of kimberlites and related magmas. Earth and Planetary Science Letter, 113, 521-538. 